\title{
Sensory Integration as a Method of Correction of Disorders of Children
}

\section{Сенсорна інтеграція як метод корекції розладів у дітей}

\author{
Olena Kiparenko \\ Postgraduate Student of Department of Social Assistance and \\ Practical Psychology, Odesa I. I. Mechnikov National University, \\ Odesa (Ukraine) \\ ORCID ID: https://orcid.org/0000-0001-8577-0108 \\ E-mail: elena.kiparenko@gmail.com
}

\section{Олена Кіпаренко}

Аспірантка кафедри соціальної допомоги та практичної психології, Одеський національний університет ім. I. I. Мечникова, м. Одеса (Україна)

\section{ABSTRACT}

The article reveals the relevance of the sensory development of junior and middle school age. The focus is made on the theoretical aspects of the sensory integration dysfunction; along with it, the basic principles of the recommended correctional work for students having both learning difficulties at school and the sensory integration dysfunction are determined.

The aim of the article is 1) to show the specific features of the sensory system development among children of 7-12 years old and how they are connected with the learning difficulties at school; 2) to describe practical recommendations for correctional work in future.

Address for correspondence, e-mail: kpnu_lab_ps@ukr.net Copyright: (c) Kiparenko Olena

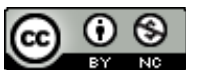
The article is licensed under CC BY-NC 4.0 International (https://creativecommons.org/licenses/by-nc/4.0/)

(C) Kiparenko Olena

DOI (article): https://doi.org/10.32626/2227-6246.2020-49.152-176 
DOI: https://doi.org/10.32626/2227-6246.2020-49 2020. випуск 49

Methods. The research was conducted on the basis of the Center for Practical Neuropsychology (Odesa) among students of 7-12 age. To assess the neuropsychological factors, we used the classic set of neuropsychological tests by $O$. R. Luria; to assess the level of sensory development, we used a questionnaire on the violation of the sensory data reduction process in a child by $K$. Kranovitz.

The results of the research. Based on the answers to the questionnaire, it was revealed that 51 (62\%) children have a violation of the sensory data reduction process, namely: a violation of the modulation of sensations (34\%), a violation of the ability to distinguish feelings (21\%), motor impairment (60\%).

Interestingly, according to the results of the neuropsychological tests, the majority of examinees had the kinetic, kinesthetic and optical-spatial factors of the movement organization not properly formed.

Considering the results of the survey and the main directions of work of scientists and specialists in sensory integration, we determined the basic principles of the recommended remedial work for students having difficulties at school and sensory integration dysfunction at the same time.

Conclusions. Systematic focused work on the schoolchildren's sensory integration has a significant positive impact on the development of all higher mental functions, thereby improving the organization of all types of children's activities, success in studying and behavior.

The study has shown that the theory and practice of the world and Ukrainian specialists in sensory integration helps to understand, explain and draw up a further remedial program for children having both learning difficulties at school and sensory integration dysfunction. This material can be used to understand how a child can apply various sensory stimuli as a compensation in order to improve attention levels, reduce the effects of stress and increase self-control and learning productivity.

Key words: sensory integration, sensory processing of information, stimulating sensory development, learning difficulties at school, neuropsychological correction, sensory diet.

\section{Вступ}

Дисфункція сенсорної інтеграції є проблемою, з якою зустрічаються різні фахівці - психологи, нейропсихологи, дефектологи, неврологи та педагоги. Дедалі зростає кількість дітей, які прийшли до школи, не отримавши свого

(C) Kiparenko Olena

DOI (article): https://doi.org/10.32626/2227-6246.2020-49.152-176 
часу якісної корекційної допомоги, і які згодом не мають можливості об'єктивно сприймати навчальний матеріал.

Спеціальної літератури стосовно порушеної теми недостатньо, діагностика і корекція розладів обробки й інтеграції сенсорних сигналів остаточно не визначена фахівцями. У MКХ-10 діагноз «дисфункція сенсорної інтеграції» не виокремлюється. Розглядається питання про включення цього розладу до DSM-6. Поки що в MКХ-10 визначено одну з форм дисфункції сенсорної інтеграції - диспраксію (F82 специфічні розлади розвитку моторної функції).

Нещодавно апаратом функціональної МРТ було зафіксовано зміни у сенсорних каналах головного мозку (задній асоціативний комплекс), завдяки чому було визначено біологічну основу дисфункції сенсорної інтеграції.

Значних труднощів зазнає вивчення проблеми формування системного підходу до теми. Клінічний спектр дисфункції занадто великий, що ускладнює вироблення єдиного підходу до критеріїв діагностики та подальшої корекційної роботи. Це зумовлює ситуацію, коли проблема серйозно не сприймається батьками, а спеціалісти різних напрямків мають доволі неоднозначні погляди на проблему.

Мета статті - дослідити сенсорну інтеграцію як метод корекції розладів у дітей.

\section{Завдання статті}

Реалізація зазначеної мети конкретизується через такі завдання:

1) здійснити теоретико-методологічний аналіз підходів до сенсорної інтеграції;

2) розкрити основні особливості розвитку сенсорної системи у дітей 7-12 років та їх зв'язок зі складнощами навчання дітей у школі;

3) запропонувати практичні рекомендації щодо здійснення корекційної роботи із сенсорної інтеграції у дітей 7-12 років.

(C) Kiparenko Olena

DOI (article): https://doi.org/10.32626/2227-6246.2020-49.152-176 


\section{Методи та методики дослідження}

Дослідження проводилися на базі Центру практичної нейропсихологій (м. Одеса) на школярах віком 7-12 років. Усі обстеження проводилися з вівторка по п'ятницю в години високої працездатності дітей. Для оцінки нейропсихологічних чинників використано класичну батарею нейропсихологічних тестів О. Р. Лурії (Golden, 1981), для оцінки рівня сенсорного розвитку - анкету-опитувальник із питань порушення у дитини процесу обробки сенсорної інформації К. Крановіц (Kranowitz, 2005).

\section{Результати та дискусії}

Джин Айрес (психолог, ерготерапевт зі США) у 1979 р. уперше визначила поняття «сенсорна депривація», що пов'язана з порушеннями сенсорних відчуттів, сенсорної обробки інформації. Дж. Айрес дала визначення сенсорної інтеграції, описала її загальні принципи та положення, важливість для розвитку дитини (Ayres, 2005).

Подальшою розробкою теми займалася їі співвітчизниця Керол Сток Крановіц - фахівець із навчання та розвитку дітей. К. Крановіц запропонувала ефективні техніки і вправи для вирішення сенсорних проблем у школі та вдома (Kranowitz, 2005).

Провідну роль сенсорного розвитку і побудову роботи з дітьми досліджувало чимало науковців.

Дж. Айріс розробила теорію сенсорної інтеграції, стандартизувала методику оцінки рівня розвитку означеної сфери і комплекс вправ, які використовуються при роботі з пацієнтами (Ayres, 2005). Патриція Вілбаргер уперше описала поняття «сенсорна дієта» (Wilbarger, 2002).

Серед вітчизняних науковців можна виокремити А. Заплатинську, яка на дисертаційному рівні дослідила технологію сенсорної інтеграції у корекційній педагогіці (Заплатинська, 2016). Також проблему висвітлювали Н. І. Литвин, 
DOI: https://doi.org/10.32626/2227-6246.2020-49

О. В. Борецька, О. В. Сойко (Литвин, Борецька \& Сойко, 2018), Т. Скрипник (Скрипник, 2016), Т. М. Фаласеніді, М. Я. Козак (Фаласеніді \& Козак, 2017), А. П. Чуприков, T. В. Чорна (Чуприков \& Чорна, 2017).

Загалом кількість вітчизняних публікацій, присвячених сенсорній інтеграції, є дуже обмеженою. При цьому досі не визначено особливості корекційної роботи для школярів зі складнощами навчання у школі та дисфункцією сенсорної інтеграції одночасно.

На базі Центру практичної нейропсихології (м. Одеса) в період із 01.07.2018 р. по 01.07.2019 р. було проведено 82 нейропсихологічних обстеження школярів вікової категорії від 7 до 12 років. Озвучені батьками проблеми, з якими вони звернулися до нейропсихолога, були такими: неуважність 75 (91\%), непосидючість - 70 (85\%), труднощі з письмом $50(60 \%)$, труднощі з читанням - 63 (77\%), стомлюваність 25 (30\%), уповільненість - 38 (46\%), гіперактивність - 42 (51\%), труднощі концентрації уваги - 80 (98\%), байдужість до поганих оцінок - 12 (15\%), відсутність бажання навчатися - 37 (45\%), неуважність - 44 (54\%), погана пам'ять - 21 (26\%), інші складнощі - 16 (20\%).

Разом зі стандартною анкетою-опитувальником із вивчення дитини батькам також було запропоновано анкету-опитувальник із питань порушення у дитини процесу обробки сенсорної інформації (Kranowitz, 2006: 271). За результатами анкети було виявлено, що у 51 дитини (62\%) відбувається розлад процесу обробки інформації, а саме: розлад модуляції відчуттів (34\%); розлад уміння розрізняти відчуття (21\%); рухові проблеми (60\%).

Загальний огляд проблем представлено у табл. 1-3.

Ми діагностували, що третина дітей із вибірки мають проблему з модуляцією відчуттів. Переважно це положення тіла і контроль мускулатури, м'язовий контроль - $30 \%$ від загальної вибірки.

(C) Kiparenko Olena

DOI (article): https://doi.org/10.32626/2227-6246.2020-49.152-176 
Загальний огляд виявлених проблем модуляції відчуттів (у дитини може бути одна чи кілька проблем)

\begin{tabular}{|l|c|c|c|c|}
\hline & \multicolumn{3}{|c|}{ Відчуття } & \multirow{2}{*}{ Дотик } \\
\cline { 2 - 4 } & $\begin{array}{c}\text { Рух і } \\
\text { баланс }\end{array}$ & $\begin{array}{c}\text { Положення тіла і } \\
\text { контроль мускулатури, } \\
\text { м'язовий контроль }\end{array}$ & \\
\hline Кількість & 7 & 16 & 25 & 28 \\
\hline $\begin{array}{l}\text { \% від загаль- } \\
\text { ної вибірки }\end{array}$ & 8 & 19,5 & 30 & 34 \\
\hline
\end{tabular}

Труднощі з дотиками, рухами і положенням тіла є сигнальними ознаками порушень обробки сенсорної інформації. Дитина може незвично реагувати на зорові відчуття, звуки, запахи і смаки. У зоровій сфері дитина матиме короткий зоровий контакт, неуважність до роботи за письмовим столом, буде завжди стривожена і пильна (підвищена чутливість) або, навпаки, ігноруватиме нові візуальні стимули, повільно реагуватиме на об'єкти, що наближаються (знижена чутливість). У слуховий сфері дитина з підвищеною чутливістю сильно відволікатиметься на будь-який шум, який інші діти не помічають, або, навпаки, ігноруватиме деякі звуки і голоси (зі зниженою чутливістю). Ці процеси в першу чергу викликають труднощі шкільного навчання (Kranowitz, 2006: 48).

таблиия 2

Загальний огляд виявлених проблем з умінням розрізняти відчуття (у дитини може бути одна чи кілька проблем)

\begin{tabular}{|l|c|c|c|c|}
\hline & \multicolumn{3}{|c|}{ Відчуття } & \multirow{2}{*}{ Дотик } \\
\cline { 2 - 4 } & $\begin{array}{c}\text { Рух і } \\
\text { баланс }\end{array}$ & $\begin{array}{c}\text { Положення тіла і } \\
\text { контроль мускулатури, } \\
\text { м'язовий контроль }\end{array}$ & \\
\hline Кількість & 11 & 8 & 17 & 17 \\
\hline $\begin{array}{l}\text { \% від загаль- } \\
\text { ної вибірки }\end{array}$ & 13 & 10 & 21 & 21 \\
\hline
\end{tabular}

(C) Kiparenko Olena

DOI (article): https://doi.org/10.32626/2227-6246.2020-49.152-176 
Як бачимо, 21\% дітей із вибірки мають проблему з модуляцією відчуттів. Переважно це також положення тіла i контроль мускулатури - $21 \%$ від загальної кількості.

У дітей із проблемами розрізняти відчуття найчастіше $\epsilon$ рухові порушення, що базуються на труднощах сенсорної інтеграції. У них також виникають проблеми із зоровим гнозисом (плутаються в схожості й відмінності літер, картинок, плутаються з розташуванням об’єктів у просторі - таблиць, колонок). Діти із зазначеними труднощами в повному обсязі не розуміють, як рухатися самому, щоб не стикатися 3 об’єктами у навколишньому просторі.

Таблиия 3

Загальний огляд виявлених рухових проблем (у дитини може бути одна чи кілька проблем)

\begin{tabular}{|l|c|c|c|c|c|c|}
\hline $\begin{array}{c}\text { Рухові } \\
\text { навички, що } \\
\text { базуються на } \\
\text { відчуттях }\end{array}$ & $\begin{array}{c}\text { Компо- } \\
\text { ненти } \\
\text { руху }\end{array}$ & $\begin{array}{c}\text { Рівно- } \\
\text { вага }\end{array}$ & $\begin{array}{c}\text { Білате- } \\
\text { ральна } \\
\text { коорди- } \\
\text { нація }\end{array}$ & $\begin{array}{c}\text { ральль-- } \\
\text { коорди- } \\
\text { нація }\end{array}$ & $\begin{array}{c}\text { Перетин } \\
\text { середин- } \\
\text { ної лінії }\end{array}$ & Усього \\
\hline Кількість & 31 & 6 & 45 & 4 & 28 & 49 \\
\hline $\begin{array}{l}\text { \% від загаль- } \\
\text { ної вибірки }\end{array}$ & 38 & 7 & 55 & 5 & 34 & 60 \\
\hline
\end{tabular}

Ми діагностували, що дві третини дітей із вибірки мають рухові проблеми. Переважно це білатеральна координація - у 55\% від загальної кількості.

У дітей, які мають рухові проблеми, ми відзначаємо слабкий тонус м'язів, слабке захоплення предметів, труднощі $з$ підтриманням нерухомої пози. Також характерні проблеми з дією, диспраксії. Дитина може мати труднощі з розумінням, як виконати складний рух, зі стеженням за об'єктом (учитель, рядок у книзі при читанні, списування із зразка), мати складнощі з моторикою, а саме із завданнями, пов'язаними з руками (малювання, письмо) (Kranowitz, 2006: 52).

(C) Kiparenko Olena

DOI (article): https://doi.org/10.32626/2227-6246.2020-49.152-176 
Важливим виявилося те, що у більшості досліджуваних за результатами нейропсихологічного обстеження було виявлено недостатню сформованість кінетичного, кінестетичного й оптико-просторового чинників організації руху (табл. 4).

таблищя 4

Перелік помилок школярів у дослідженні

\begin{tabular}{|l|c|c|c|}
\hline \multicolumn{1}{|c|}{ Назва проби } & $\begin{array}{c}\text { Кінетичні } \\
\text { помилки }\end{array}$ & $\begin{array}{c}\text { Кінесте- } \\
\text { тичні } \\
\text { помилки }\end{array}$ & $\begin{array}{c}\text { Оптико-просто- } \\
\text { рові помилки } \\
\text { органації рухів }\end{array}$ \\
\hline Праксис пози пальців & - & 70 & - \\
\hline Одноручні (просторові) & - & - & 31 \\
\hline Дворучні (просторові) & - & - & 53 \\
\hline Динамічний праксис & 37 & - & 68 \\
\hline Реципрокна координація & 42 & - & - \\
\hline
\end{tabular}

Ми діагностували, що переважна більшість дітей мають проблеми з праксисом. Здебільшого, це кінестетичні помилки $-70(85 \%)$ й оптико-просторові помилки організації рухів $-68(83 \%)$.

Відповідно до теорії М. О. Бернштейна, тільки система аферентних синтезів може забезпечити правильний перебіг рухового акту. Система аферентацій повинна включати до свого складу врахування зорово-просторових координат, систему кінестетичних сигналів, які вказують на стан опорно-рухового апарату, сигналів загального тонусу м'язів, стану рівноваги тощо.

За умови, що аферентні сигнали надходитимуть постійно, ми можемо говорити про успішний перебіг кожної повільної дії із здійсненням контролю над нею і можливістю виправлення помилок (Лурия, 2009: 250).

Результати дослідження (табл. 4) демонструють несформованість кінетичного, кінестетичного й оптико-просторового чинників організації руху, що є причиною шкільної

(C) Kiparenko Olena

DOI (article): https://doi.org/10.32626/2227-6246.2020-49.152-176 
DOI: https://doi.org/10.32626/2227-6246.2020-49 2020. випуск 49

неуспішності внаслідок неможливості виконання потрібного завдання.

Отже, ми дійшли до висновку, що корекційну програму дітей зі складнощами навчання у школі необхідно будувати у такій спосіб, щоб до неї були включені вправи з подолання дисфункції сенсорної інтеграції. Далі у нашій розвідці ми пояснимо чому це важливо.

Останнім часом однією з найобговорюваніших причин шкільної неуспішності учнів молодших класів є порушення обробки сенсорної інформації. Важливим показником зрілості мозкових структур першокласника є сенсорна (сенсомоторна) інтеграція, яка є показником точності й швидкості сенсомоторної реакції. Сенсорна інтеграція також є фундаментальною основою для успішної інтелектуальної діяльності школяра.

Окрім того, проблема дисфункції сенсорної інтеграції актуальна у зв'язку з порушенням осанки у дітей. Саме в сучасних умовах порушення осанки доволі поширене і набуло як медичної, так і психологічної значущості. Проведені дослідження дають змогу обгрунтувати профілактику порушень постави й опорно-рухового апарату, включаючи наукові пошуки у галузі фізіології сенсорних систем дитини (Richardson, Atwater, Crowe \& Deitz, 1992).

Відповідно до теорії функціональних систем стійкість вертикальної пози забезпечується за рахунок сенсорної інтеграції різних систем організму (зорової, вестибулярної, пропріоцептивної, тактильної тощо), на основі аналізу яких формується алгоритм моторної координації (Richardson, Atwater, Crowe \& Deitz, 1992). У багатьох наукових дослідженнях із фізіології опорно-рухового апарату вже досить давно була доведена визначальна роль сенсорних систем організму в довільному управлінні м'язовою напругою і розподілі м'язового тонусу. Встановлено, що якість управління м'язовою напругою визначається ефективністю сенсорних систем (Бернштейн, 1990: 323).

(C) Kiparenko Olena

DOI (article): https://doi.org/10.32626/2227-6246.2020-49.152-176 
Сенсорна інтеграція:

- $є$ несвідомим процесом, що відбувається в головному мозку (ми не замислюємося про неї, як не замислюємося про дихання);

- організовує інформацію, отриману за допомогою органів чуттів (смак, вигляд, запах, дотик, звуки, рухи, вплив сили тяжіння, положення у просторі тощо);

- наділяє значенням відчуття, фільтруючи інформацію та відбираючи те, на чому слід сконцентруватися (наприклад, слухати вчителя і не звертати при цьому увагу на сторонній шум);

- дозволяє осмислено діяти та реагувати на ситуацію, у якій ми знаходимося (адаптивна відповідь);

- формує базу для теоретичного навчання й соціальної поведінки (Ayres, 2005: 18).

Ступені сенсорної інтеграції:

1) самосприйняття, яке включає пропріоцепцію, вібраційні відчуття, вестибулярні відчуття;

2) контактні відчуття (дотик, тактильні відчуття), відчуття смаку, зір, слух;

3) мова, підрахунок, самооцінка, увага, регуляція, поведінка, творчість.

Сенсорна обробка включає в себе безпосередньо обробку, інтеграцію та модуляцію інформації від органів чуття й сенсорних систем (аналізаторів), інформації, що надходить iз навколишнього середовища та від власного тіла. Сенсорна інтеграція - це здатність дитини й дорослої людини організувати отримані відчуття для здійснення дій, рухів, навчання й організації адекватної поведінки (Бернштейн, 1990: 402). Вивчення сенсорного профілю дитини в американських і європейських клініках сьогодні включено в програму нейропсихологічного й психологічного обстеження. Порушення сенсорної обробки інформації вважається комплексним розладом роботи головного мозку, в процесі якого дитина сприймає й інтерпретує отриману інформацію (c) Kiparenko Olena

DOI (article): https://doi.org/10.32626/2227-6246.2020-49.152-176 
з повсякденного життя неправильно, що згодом призводить до проблем із навчанням, координацією рухів, поведінкою і мовою (Bundy, Lane \& Murray, 2002: 71).

К. Крановіц зазначає, що порушення обробки сенсорної інформації роблять дитину розбалансованою, а саме:

- дитина не спроможна до адаптивних відповідей;

- дитина не розуміє причинно-наслідкові зв'язки у явищах, які її оточують;

- спостерігається безладність розвитку (дисгармонія);

- виконання звичайних завдань може стати складним випробуванням для дитини (Kranowitz, 2006: 45).

При порушенні процесу обробки сенсорної інформації дитина стикається з певними труднощами.

1. Проблеми саморегуляції (часті перепади настрою, дитина неврівноважена, не може зупинитися, переключитися).

2. Засинання (такі діти навіть у молодшому шкільному віці можуть спати з батьками, уві сні є потреба в русі, у ліжку часто виникає відчуття дискомфорту, заважають заснути запахи або піжама, яка занадто дряпає, дитина не може спати під легкою ковдрою або, навпаки, вимагає занадто важку).

3. Харчування (не сприймає зовнішній вигляд і колір їжі, наприклад, зустрічаються діти, які не могли їсти червоні продукти. Присутня вибірковість у їжі).

4. Проблеми з порушенням рівня активності й уваги (дітям властиво бути весь час у русі, вони неспокійні, запальні, роздратовані, безцільно граються).

5. Знижена здатність до адаптації (важко зустрічатися 3 новими людьми, проблеми з дружбою і комунікацією, часто наявні емоційні проблеми).

6. Когнітивні порушення (проблеми з читанням, підрахунком і письмом).

7. Дислексія (виділимо її окремо, оскільки це проблема з читанням, написанням і вимовою незалежно від розумових здібностей і мотивації).

(C) Kiparenko Olena

DOI (article): https://doi.org/10.32626/2227-6246.2020-49.152-176 
8. Синдром дефіциту уваги з гіперактивністю (СДУГ), розлад аутистичного спектра (РАC), синдром Аспергера, невербальні когнітивні розлади, елективний мутизм та інші розлади.

Коротко розглянемо, яким чином проходить процес сенсорної інтеграції в дошкільному віці та його подальший вплив на успішність навчання.

У дошкільному віці у дітей із дисфункцією сенсорної інтеграції спостерігаються порушення ігрової діяльності. Дитині складно видавати адаптивну відповідь на сигнали, що надходять від очей, вух, тіла. Дитина не ідентифікує те, що відчуває. Вона не сприймає інформацію повністю, пропускає деталі. Такі діти моторно незграбні, часто ламають іграшки та мають проблеми під час групових дитячих ігор. У дітей із такими складнощами часто зустрічаються затримки мовного розвитку. Деякі з них не чують співрозмовника, але слух вони мають на рівні норми.

Слабка тактильна чутливість є причиною гіперактивної поведінки, діти роздратовуються від яскравого світла, гучного шуму (Richardson, Atwater, Crowe \& Deitz, 1992: 796).

Поступово, по мірі дорослішання, деякі сенсомоторні процеси заміщуються ментальними й соціальними навичками. Сенсорна інтеграція необхідна для руху, мови та гри, але в подальшому вона слугує фундаментом для складніших дій і супроводжує процеси читання, письма та соціальної поведінки.

Процес обробки сенсорної інформації працює так, що зайві зовнішні імпульси гальмуються мозком. Коли дитина

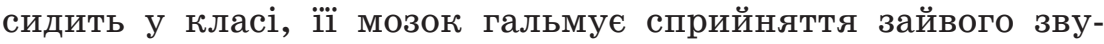
ку, якщо вона налаштована слухати вчителя. Якщо не блокується непотрібна інформація, мозок може бути надмірно стимульований. Дитина звикає до певних сенсорних відчуттів (наприклад, шуму за вікном), мозок автоматично ігнорує їх, тим самим полегшуючи сприйняття приємних або потрібних відчуттів.

(c) Kiparenko Olena

DOI (article): https://doi.org/10.32626/2227-6246.2020-49.152-176 
DOI: https://doi.org/10.32626/2227-6246.2020-49

На практиці часто спостерігаємо, що у дітей досить часто порушується нормальна робота системи, яка сприймає інформацію. Дитина виявляється не здатною правильно реагувати на певну сенсорну інформацію. Коли інформації занадто багато, мозок перевантажений, i це примушує дитину уникати нових вражень.

Подальша корекційна робота. Ураховуючи результати обстеження й основні напрямки роботи науковців і спеціалістів із сенсорної інтеграції, нами було визначено базові положення рекомендованої корекційної роботи для школярів зі складнощами навчання у школі та дисфункцією сенсорної інтеграції одночасно.

Корекційна робота зі школярами повинна відбуватися переважно в ігровій формі. Для цього використовуються дидактичні, рухливі, настільні ігри, спрямовані на виокремлення властивостей предметів. Форми роботи різноманітні й дають змогу психологу, спираючись на мимовільну увагу дітей, формувати елементи пізнавальних процесів, створювати у них позитивне емоційне ставлення до занять, предметів і діяльності з ними.

Напрями сенсорної інтеграції: створення спеціальних середовищних умов, які полегшують сприйняття навколишнього світу (носіння в кишені маленького предмета, розгойдування в гамаку, на гойдалках, навушники, носіння окулярів із захисним фільтром); розвиток способів полісенсорного сприйняття (вдосконалення окремих перцептивних умінь, спільна діяльність різних сенсорних систем).

У процесі сприйняття у школярів поступово розширюватиметься слуховий, зоровий, руховий, дотиковий, смаковий досвід. Завдання психолога - сприяти об'єднанню цього досвіду й практичної діяльності.

Корекційна робота матиме ефект і результат, навіть якщо інформація про першопричини захворювання не є вичерпною. Досить знати, від якого аналізатора сенсорна інформація надходить неповною мірою або у спотворений спосіб. (c) Kiparenko Olena

DOI (article): https://doi.org/10.32626/2227-6246.2020-49.152-176 
Етап попередньої діагностики при корекційній роботі включає в себе вивчення початкових діагнозів школяра, збір медичного анамнезу. Фахівець із сенсорної інтеграції вивчає медичні висновки лікарів, діагнози невропатолога, логопеда-дефектолога, психіатра тощо. Під час цього етапу проводиться бесіда з батьками, результатом якої є отримання максимально точної та повної інформації про дитину. Психолог вислуховує запити батьків, педагогів, відстежує ïх очікування від занять, відповідно до цього вибудовуючи згодом низку навчальних завдань. Психолог також уточнює соціально-побутові дані (скільки дітей у родині, чи сім'я $\epsilon$ повною, з ким проживає дитина, проживає сім'я в місті або в сільській місцевості тощо). Далі він здійснює особистісну характеристику дитини, уточнюючи, що їй більше подобається, чого дитина боїться, чи має фобії або яскраво виражені невмотивовані страхи. Корекційна робота певною мірою може бути стресом для школяра, тому необхідно виключити додаткові джерела збудження нервової системи, не допускаючи впливу чинників, віднесених до психологічних протипоказань. Також слід ураховувати можливу наявність у дитини фізичних обмежень. Наприклад, при супутній епілепсії застосовуються з великою обережністю або виключаються зовсім обертання, мерехтіння, світлові спалахи, тактильна стимуляція, незнайомі речі тощо. Схильність до вивихів, наявність проблем із суглобами спричиняють обмеження рухової активності дитини. У таких випадках слід обережно ставитися до стрибків, бігу, в т. ч. бігу з перешкодами, пересування із заплющеними очима тощо. Обтяження перебігу захворювання наявністю алергічних компонентів може стати причиною заборони на взаємодію з деякими матеріалами.

Після отримання необхідної загальної інформації про дитину відбувається етап спостереження за учнем у ході організації вільної гри у просторі сенсорної кімнати. Етапи попередньої діагностики і спостереження інколи можуть

(c) Kiparenko Olena

DOI (article): https://doi.org/10.32626/2227-6246.2020-49.152-176 
тривати до трьох місяців. Потрібен час для достовірного i повного аналізу, що передує складанню індивідуального сенсорного профілю школяра.

Складаючи індивідуальний сенсорний профіль дитини, психологом вивчаються всі аналізатори, визначається наявність чутливих реакцій і способів реагування, помилок сприйняття. Уникнення відчуттів може свідчити про гіперчутливість, пошук відчуттів виражається в гіпочутливості, труднощі обробки інформації свідчать про сенсорні порушення.

Труднощі обробки будуть помітні не одразу, реакції будуть різноманітні, але не досить адекватні щодо зовнішнього подразника. Отримані по кожній дитині результати записуються у спеціальний профайл.

Під час спостереження за дитиною вивчається велика моторика - постуральний контроль, контроль рухів очей, взаємодія лівої та правої сторін тіла; а також дрібна моторика. Аналізуються можливості дитини задля ефективнішого планування корекційної діяльності в контексті сюжетно-рольової гри.

Важливо пам'ятати, що будь-яке порушення сенсорної інтеграції має під собою неврологічну основу. Навіть якщо стандартні методи нейрофізіологічного обстеження не підтвердили передбачуваний діагноз, не виключені порушення біохімічних процесів організації мозкової діяльності. Порушення сенсорної інтеграції особливо виразно помітні при сторонньому спостереженні за дитиною і свідчать про дезорганізацію їі відчуттів.

Більшість вправ на розвиток руху проводяться на підлозі. Вони спрямовані на розвиток посадки голови відносно тіла (що є основою правильної осанки) і здібностей користуватися правою-лівою сторонами та верхньою й нижньою частинами тіла у різних варіантах (що є основою координації). Спочатку дитина повинна виконувати прості вправи та згодом переходити до складніших. Рухова програма розробля(c) Kiparenko Olena

DOI (article): https://doi.org/10.32626/2227-6246.2020-49.152-176 
ється для кожної дитини окремо. Прикладом можуть бути вправи «повітряний млин», «гусениця», «цікава гусениця», «восьминіг», «рибка», «ящірка» тощо.

Також до рухової програми обов'язково повинні бути включені кінезіологічні вправи комплексу «Гімнастика для мозку» Пола та Гейла Деннісонів. Рухові вправи треба виконувати щоденно по 10-15 хвилин упродовж 6-12 місяців.

Наступним етапом є розробка занять із використанням методики сенсорної інтеграції, тобто складання сенсорної дієти. Сенсорна дієта являє собою змістовний план занять i вправ для поступового насичення дитини необхідними додатковими сенсорними стимулами. Заняття можуть проводитися в спеціальних кімнатах сенсорної інтеграції у форматі вільної гри, в ході сюжетно-рольової гри під контролем фахівця. За формою це можуть бути індивідуальні та групові заняття.

Сенсорна дієта є ретельно структурованим індивідуальним планом занять і процедур, що забезпечують введення сенсорних стимулів, необхідних дитині, щоб залишатися зосередженою й організованою упродовж дня.

Результати сенсорної дієти стають відчутними досить швидко. Впливи, які збуджують дитину чи заспокоюють іï, діють ефективно не тільки на певний момент, вони упродовж тривалого часу фактично допомагають розбудовувати нервову систему дитини так, щоб вона мала змогу краще:

- переносити незнайомі відчуття, бути терплячішою в складних ситуаціях;

- регулювати настороженість і покращити увагу;

- обмежити сенсорний пошук і відхилення в сенсорній поведінці;

- сприймати будь-які зміни з меншим стресом.

Сенсорна дієта включає (залежно від гіпер- або гіпочутливості дитини):

- пропріоцептивну стимуляцію (молодшим школярам треба достатньо стрибати - на батуті, граючи в «класики», (C) Kiparenko Olena

DOI (article): https://doi.org/10.32626/2227-6246.2020-49.152-176 
DOI: https://doi.org/10.32626/2227-6246.2020-49 2020. випУск 49

на фітнес-м'ячі, також дитина повина носити щось відносно важке - наприклад, пилосос, книги, вологу білизну з пральної машини);

- вестибулярну стимуляцію (висіти вниз головою, робити «сонечко» на турніках, качатися, обертатися на гойдалках і каруселях);

- тактильну стимуляцію (їсти заморожені фрукти або овочі, змішувати холодні продукти з гарячими, ходити без взуття по піску або траві, частіше переодягатися в одяг різної фактури);

- слухову стимуляцію (прислухатися до співу птахів, слухати аудіозапис звуків природи, грати на музичних інструментах);

- візуальну стимуляцію (при цьому виключити дратуючі візуальні стимули, кольори);

- нюхову стимуляцію (ігри у відгадування запахів, створення власної колекції запахів батьками для дитини);

- смакову стимуляцію (ігри у відгадування смаків, перед вживанням продукту з новим смаком давати продукт насиченого смаку, готувати їжу разом із дитиною).

Загалом, завдяки грі психолог створює ситуацію, коли дитина змушена йти на контакт із незнайомим зовнішнім подразником, завдяки мотивації ігровою діяльністю. Задля цього можуть застосовуватися ігри з елементами змагання й суперництва, ігри, що включають отримання бажаної речі, «нагороди» .

Під час ігрової діяльності існує можливість за мінімального впливу психолога підключити необхідний для подальшого навчання додатковий сенсорний стимул. Так, дитина 3 гіперчутливістю вестибулярного рецептора боїться стати на балансир у ході цілеспрямованої навчальної діяльності. Проте вона, можливо, не відмовиться від цієї дії, опинившись у спеціально змодельованій ігровій ситуації: наприклад, коли потрібно пройти естафету 3 перешкодами або стати на балансир, щоб «ловити» макети риб на магнітну вудку.

(C) Kiparenko Olena

DOI (article): https://doi.org/10.32626/2227-6246.2020-49.152-176 
У кімнаті сенсорної інтеграції можуть застосовуватися різноманітні засоби навчання: спортивний інвентар хула-хупи, басейн із легкими кулями, важкі м'ячі, легкі м'ячі, спортивні мати, дитячі ігрові комплекси, гойдалки, роликові дошки тощо; підручні матеріали - щітки, валики, нерівні поверхні, мотузкові сходи, сипучі матеріали (пісок, пінопласт, дрібні предмети), «повітряні» матеріали (піна для гоління, збиті вершки тощо), пластичні матеріали (кульковий пластилін, полімерна глина тощо); медичне обладнання - масажні килимки, роликові масажери; спеціальне обладнання для сенсорної інтеграції - балансири, сенсорні мішки (еластичні, нееластичні з обтяжуванням), сенсорні ковдри (легкі, з навантаженням) і багато іншого.

Після того, як школяр неодноразово успішно контактує з додатковими сенсорними стимулами в рамках спеціально організованої ігрової діяльності, рекомендується розширити діапазон застосування методу, включивши елементи сенсорної інтеграції в навчальну діяльність у рамках загальноосвітнього процесу: застосування платформи, що розгойдується, для забезпечення додаткової вестибулярної стимуляції, використання заспокійливого прогумованого кільця на шиї у якості додаткового пропріоцептивного стимулу тощо.

Методика сенсорної інтеграції успішно застосовується в поєднанні з традиційними психологічними підходами, такими як створення «ситуації успіху», організація в ході ігрової діяльності умов для формування у школяра додаткової мотивації до контакту із сенсорним стимулом. Класичне цілепокладання й багатозадачність навчальної діяльності дозволяють повною мірою реалізувати всі можливості методики сенсорної інтеграції як в ігровій формі (з метою поліпшення соціальної адаптації дітей у суспільстві), так і у форматі стандартного навчання.

При побудові заняття з використанням елементів сенсорної інтеграції дуже важливо постійно діяти в зоні комфорту дитини. У разі виникнення перешкод варто відступи-

(C) Kiparenko Olena

DOI (article): https://doi.org/10.32626/2227-6246.2020-49.152-176 
ти назад, потім просуватися вперед дрібнішими кроками. Забезпечити підтримку, щоб максимізувати успіх. Додавати або ускладнювати завдання тільки в зоні комфорту дитини. Завоювати їі довіру, забезпечити у дитини почуття стійкої захищеності.

Основними завданнями сенсорної інтеграції є:

1) збагачення сенсорного досвіду (отримання різних відчуттів) шляхом впливу на органи чуття;

2) розвиток зорового, слухового, тактильного, кінестетичного сприйняття;

3) подолання проблем сенсорного сприйняття (дискомфорту, що викликається конкретним стимулом-подразником).

Дуже важлива мотивація школяра. Щаслива дитина краще навчається і намагається більше зробити, тому слід ширше використовувати сюрпризи, улюблені іграшки, ляльковий театр, засоби для розвитку смакової та нюхової чутливості тощо. Веселощі - це те, що робить заняття привабливим і дає кращий результат.

\section{Висновки}

Сьогодні життя багатьох дітей є збідненим на сенсорні відчуття, тому необхідно намагатися максимально заповнити ці прогалини. Для цього використовуються нестандартні й різноманітні способи, щоб допомогти кожній дитині. До занять із сенсорної інтеграції включаються вправи на розвиток фізичних якостей і швидкості реакцій, ігри з водою, світлом, запахами та звуками. Систематична цілеспрямована робота із сенсорної інтеграції школярів має значний позитивний вплив на розвиток усіх вищих психічних функцій, тим самим покращуючи становлення усіх видів дитячої діяльності, успішність у навчанні та поведінку. Загалом, отримання своєчасної та необхідної сенсорної допомоги є життєво важливою умовою на шляху до майбутнього успіху дитини.

(C) Kiparenko Olena

DOI (article): https://doi.org/10.32626/2227-6246.2020-49.152-176 
Наведена інформація свідчить про те, що теорія та практика світових і вітчизняних спеціалістів із сенсорної інтеграції допомагає зрозуміти, пояснити і скласти подальшу корекційну програму для учнів зі складнощами навчання в школі й дисфункцією сенсорної інтеграції одночасно. Цей матеріал можна використовувати для того, щоб розуміти, як дитина компенсаторно може застосовувати різні сенсорні стимули задля поліпшення власного рівня уваги, зменшення впливу стресу, збільшення самоконтролю та продуктивності навчання.

Наша стаття не вичерпує всіх аспектів означеної проблеми. У подальшому ми плануємо проводити лонгітюдні дослідження з діагностикою школярів до і після корекційної програми з використанням методів сенсорної терапії.

\section{Література}

Бернштейн Н. А. Физиология движений и активность. Москва : Наука, 1990. $496 \mathrm{c}$.

Заплатинська А. Б. Технологія сенсорної інтеграції у корекційному вихованні дошкільників із дитячим церебральним паралічем: автореф. дис. ... канд. пед. наук: 13.00.03. Київ, 2016. 18 с.

Литвин Н. І., Борецька О. В., Сойко О. В. Комплексна психолого-педагогічна реабілітація дітей з особливими потребами засобами сенсорної інтеграції. Психологія: реальність і перспективи. 2018. Вип. 10. С. 94-100.

Лурия А.Р. Основы нейропсихологии. Москва : Академия, 2009. 384 с. Скрипник Т. Сенсорна інтеграція як підгрунтя цілісного розвитку дітей з аутизмом. Особлива дитина: навчання і виховання. 2016. № 4. C. $24-31$.

Фаласеніді Т. М., Козак М. Я. Порушення сенсорної інтеграції у дітей з особливими потребами. Молодий вчений. 2017. № 9. С. 102-105.

Чуприков А. П., Чорна Т. В. Про нетрадиційні засоби відновлення сенсорної інтеграції при дитячому аутизмі. Фітотерапія. 2017. № 3. C. $73-77$.

Ayres, J. A. (2015). Sensory integration and the child. Western Psychological Services.

Bodison, S. C., \& Parham, L. D. (2018). Specific Sensory Techniques and Sensory Environmental Modifications for Children and Youth With

(C) Kiparenko Olena

DOI (article): https://doi.org/10.32626/2227-6246.2020-49.152-176 
DOI: https://doi.org/10.32626/2227-6246.2020-49 2020. ВипУСК 49

Sensory Integration Difficulties: A Systematic Review. American Journal of Occupational Therapy, 72, 1.

Doumas, M., McKenna, R., \& Murphy, B. (2016). Postural Control Deficits in Autism Spectrum Disorder: The Role of Sensory Integration. Journal of Autism and Developmental Disorders, 46, 853-861.

Golden, C. J. (1981). Luria-Nebraska neuropsychological battery: Children's revision manual. Los Angeles : Western Psychological Services.

Kranowitz, C. S. (2006). The out-of-sync child. A Skylight Press Book. Mailloux, Z., Parham, L. D., Roley, S. S., Ruzzano, L., \& Schaaf, R. C. (2018). Introduction to the Evaluation in Ayres Sensory Integration (EASI). American Journal of Occupational Therapy, 72 (1).

Parham, L. D., Clark, G. F., Watling, R., \& Schaaf, R. (2019). Occupational Therapy Interventions for Children and Youth With Challenges in Sensory Integration and Sensory Processing: A Clinic-Based Practice Case Example. American Journal of Occupational Therapy, 73 (1).

Richardson, P. K., Atwater, S. W., Crowe, T. K., \& Deitz, J. C. (1992). Performance of preschoolers on the pediatric clinical test of sensory interaction for balance. American Journal of Occupational Therapy, $46,9,793-800$.

Schaaf, R. C., Dumont, R. L., Arbesman, M., \& May-Benson, T. A. (2018). Efficacy of Occupational Therapy Using Ayres Sensory Integration ${ }^{\circledR}$ : A Systematic Review. American Journal of Occupational Therapy, 72 (1).

Schoen, S. A., Lane, S. J., Mailloux, Z., May-Benson, T., Parham, L. D., \& Smith Roley, S., et al. (2019). A systematic review of ayres sensory integration intervention for children with autism. Autism Research, 12 (1), 6-19.

Wilbarger, J., \& Wilbarger, P. (2002). The Wilbarger approach to treating sensory defensiveness. A. Bundy, S. Lane, \& E. Murray (Eds.). Sensory Integration: Theory and Practice. Philadelphia : F. A. Davis.

\section{References}

Bernshtein, N. A. (1990). Fiziologiia dvizhenii $i$ aktivnost [Physiology of movements and activity]. Moskva : Nauka [in Russian].

Zaplatynska, A. B. (2016). Tekhnolohiia sensornoi intehratsii u korektsiinomu vykhovanni doshkilnykiv iz dytiachym tserebralnym paralichem [Sensory integration technology in correctional education of preschool children with cerebral palsy]. Extended abstract of candidate's thesis. Kyiv [in Ukrainian].

Lytvyn, N. I., Boretska, O. V., \& Soiko, O. V. (2018). Kompleksna psykholoho-pedahohichna reabilitatsiia ditei z osoblyvymy potrebamy zaso-

(C) Kiparenko Olena

DOI (article): https://doi.org/10.32626/2227-6246.2020-49.152-176 
bamy sensornoi intehratsii [Complex psychological and pedagogical rehabilitation of children with special needs by means of sensory integration]. Psykholohiia: realnist $i$ perspektyvy - Psychology: the reality and perspectives, 10, 94-100 [in Ukrainian].

Luriia, A. R. (2009). Osnovy neiropsikhologii [Basics of Neuropsychology]. Moskva : Akademiia [in Russian].

Skrypnyk, T. (2016). Sensorna intehratsiia yak pidgruntia tsilisnoho rozvytku ditei $\mathrm{z}$ autyzmom [Sensory integration as a basis for holistic development of children with autism]. Osoblyva dytyna: navchannia $i$ vykhovannia - Special Child: training and education, 4, 24-31 [in Ukrainian].

Falasenidi, T. M., \& Kozak, M. Ya. (2017). Porushennia sensornoi intehratsii u ditei z osoblyvymy potrebamy [Violation of sensory integration of children with special needs]. Molodyi vchenyi - Young scientist, 9, 102-105 [in Ukrainian].

Chuprykov, A. P., \& Chorna, T. V. (2017). Pro netradytsiini zasoby vidnovlennia sensornoi intehratsii pry dytiachomu autyzmi [About unconventional means of restoring sensory integration in children autism]. Fitoterapiia - Phytotherapy, 3, 73-77 [in Ukrainian].

Ayres, J. A. (2015). Sensory integration and the child. Western Psychological Services.

Bodison, S. C., \& Parham, L. D. (2018). Specific Sensory Techniques and Sensory Environmental Modifications for Children and Youth With Sensory Integration Difficulties: A Systematic Review. American Journal of Occupational Therapy, 72, 1.

Doumas, M., McKenna, R., \& Murphy, B. (2016). Postural Control Deficits in Autism Spectrum Disorder: The Role of Sensory Integration. Journal of Autism and Developmental Disorders, 46 (3), 853-861.

Golden, C. J. (1981). Luria-Nebraska neuropsychological battery: Children's revision manual. Los Angeles : Western Psychological Services.

Kranowitz, C. S. (2006). The out-of-sync child. A Skylight Press Book.

Mailloux, Z., Parham, L. D., Roley, S. S., Ruzzano, L., \& Schaaf, R. C. (2018). Introduction to the Evaluation in Ayres Sensory Integration (EASI). American Journal of Occupational Therapy, 72 (1).

Parham, L. D., Clark, G. F., Watling, R., \& Schaaf, R. (2019). Occupational Therapy Interventions for Children and Youth With Challenges in Sensory Integration and Sensory Processing: A Clinic-Based Practice Case Example. American Journal of Occupational Therapy, 73 (1).

Richardson, P. K., Atwater, S. W., Crowe, T. K., \& Deitz, J. C. (1992). Performance of preschoolers on the pediatric clinical test of sensory interaction for balance. American Journal of Occupational Therapy, $46,9,793-800$.

(C) Kiparenko Olena

DOI (article): https://doi.org/10.32626/2227-6246.2020-49.152-176 
Schaaf, R. C., Dumont, R. L., Arbesman, M., \& May-Benson, T. A. (2018). Efficacy of Occupational Therapy Using Ayres Sensory Integration ${ }^{\circledR}$ : A Systematic Review. American Journal of Occupational Therapy, $72(1)$.

Schoen, S. A., Lane, S. J., Mailloux, Z., May-Benson, T., Parham, L. D., \& Smith Roley, S., et al. (2019). A systematic review of ayres sensory integration intervention for children with autism. Autism Research, $12(1), 6-19$.

Wilbarger, J., \& Wilbarger, P. (2002). The Wilbarger approach to treating sensory defensiveness. A. Bundy, S. Lane, \& E. Murray (Eds.). Sensory Integration: Theory and Practice. Philadelphia: F. A. Davis.

\section{Кіпаренко Олена. Сенсорна інтеграція як метод корекції розладів у dimeŭ}

\section{АНОТАЦІЯ}

У статті розкрито актуальність сенсорного розвитку дитини молодшого та середнього шкільного віку. Акцентовано увагу на теоретичних аспектах дисрункції сенсорної інтеграції та визначено базові положення рекомендованої корекційної роботи для школярів зі складнощами навчання у школі та дисфункцією сенсорної інтеграції одночасно.

Мета статmi - розкрити основні особливості розвитку сенсорної системи у дітей 7-12 років і їх зв'язок зі складнощами навчання дітей у школі, описати практичні рекомендації для корекційної роботи.

Методи. Дослідження проводилися на базі Центру практичної нейропсихологій (м. Одеса) на школярах 7-12 років. Для оцінки нейропсихологічних чинників використано класичну батарею нейропсихологічних тестів О. Р. Лурії, для оцінки рівня сенсорного розвитку - анкету-опитувальник із питань порушення у дитини прочесу обробки сенсорної інформачії К. Крановіц.

Результати дослідження. За результатами анкети було виявлено, що у 51 дитини (62\%) відбувається порушення прочесу обробки інформації, а саме: порушення модулячії відчуттів - 34\%; порушення вміння розрізняти відчуття - 21\%; рухові порушення -60\%.

Важливим виявилося те, що у більшості досліджуваних за результатами нейропсихологічного обстеження було виявлено недостатню сформованість кінетичного, кінестетичного й оптико-просторового чинників організації руху.

(C) Kiparenko Olena

DOI (article): https://doi.org/10.32626/2227-6246.2020-49.152-176 
Ураховуючи результати обстеження й основні напрямки роботи науковців і спеціалістів із сенсорної інтеграції, нами було визначено базові положення рекомендованої корекційної роботи для школярів зі складнощами навчання у школі та дисфункцією сенсорної інтеграції одночасно.

Висновок. Систематична чілеспрямована робота із сенсорної інтеграції школярів має значний позитивний вплив на розвиток усіх вищих психічних функцій, тим самим покращуючи організацію усіх видів дитячої діяльності, успішність у навчанні та поведінку.

Дослідження засвідчило, що теорія й практика світових і вітчизняних спеціалістів із сенсорної інтеграції допомагає зрозуміти, пояснити та скласти подальшу корекційну програму для дітей зі складнощами навчання у школі та дисфункцією сенсорної інтеграції одночасно. Цей матеріал можна використовувати для того, щоб розуміти, як дитина компенсаторно може застосовувати різні сенсорні стимули для поліпшення рівня уваги, зменшення впливу стресу, збільшення самоконтролю та продуктивності навчання.

Ключові слова: сенсорна інтеграція, сенсорна обробка інформації, стимуляція сенсорного розвитку, труднощі навчання у школі, нейропсихологічна корекція, сенсорна дієта.

\section{Кипаренко Елена. Сенсорная интеграция как метод коррекции наруше- ний у детей}

\section{АННОТАЦИЯ}

В статье раскрыта актуальность сенсорного развития ребенка младшего и среднего школьного возраста. Акцентировано внимание на теоретических аспектах дисфункции сенсорной интеграции и определены базовые положения рекомендованной коррекционной работы для школьников со сложностями обучения в школе и дисфункцией сенсорной интеграции одновременно.

Цель статьи заключается в том, чтобы раскрыть основные особенности развития сенсорной системы у детей 7-12 лет и их связь со сложностями обучения детей в школе, описать практические рекомендации для коррекционной работы.

Методы. Исследования проводились на базе Центра практической нейропсихологии (2. Одесса) на школьниках 7-12 лет. Для оценки нейропсихологических фракторов использована классическая батарея

(C) Kiparenko Olena

DOI (article): https://doi.org/10.32626/2227-6246.2020-49.152-176 
нейропсихологических тестов А. Р. Лурии, для оценки уровня сенсорного развития - анкета-опросник по вопросам нарушения у ребенка процесса обработки сенсорной информации К. Крановиц.

Результаты исследования. По результатам анкеты было выявлено, что у 51 ребенка (62\%) происходит нарушение прочесса обработки информации, а именно: нарушение модуляции ощущений (34\%); нарушение умения различать ощущения (21\%); двигательные нарушения (60\%).

Важным оказалось то, что у большинства исследуемых по результатам нейропсихологического обследования была выявлена недостаточная сформированность кинетического, кинестетического и оптико-пространственного фракторов организации движения.

Учитывая результаты обследования и основные направления работы ученых и специалистов в области сенсорной интеграции, нами были определены базовые положения рекомендованной коррекционной работы для школьников со сложностями обучения в школе и дисфункцией сенсорной интеграции одновременно.

Вывод. Систематическая целенаправленная работа по сенсорной интеграции школьников имеет значительное положительное влияние на развитие всех высших психических функций, тем самым улучшая организацию всех видов детской деятельности, успешность обучения и поведение.

Исследование показало, что теория и практика мировых и отечественных специалистов в области сенсорной интеграции помогает понять, объяснить и составить дальнейшую коррекционную программу для детей со сложностями обучения в школе и дисфункцией сенсорной интеграции одновременно. Этот материал можно использовать для того, чтобы понимать, как ребенок компенсаторно может применять различные сенсорные стимулы для улучшения уровня внимания, уменьшения влияния стресса, увеличения самоконтроля и продуктивности обучения.

Ключевые слова: сенсорная интеграция, сенсорная обработка информации, стимуляция сенсорного развития, трудности обучения в школе, нейропсихологическая коррекция, сенсорная диета.

Original manuscript received March 12, 2020

Revised manuscript accepted April 28, 2020

(C) Kiparenko Olena

DOI (article): https://doi.org/10.32626/2227-6246.2020-49.152-176 